\title{
The Forms and Meanings of American Slangs Used in TED 2 Movie Scripts
}

\author{
I Gusti Bagus Kasuto Erawanto", I Gusti Ngurah Parthama \\ English Departement, Faculty of Arts, Udayana University \\ [Gustikasuto96@gmail.com], [ignparthama@gmail.com] \\ Denpasar, Bali, Indonesia \\ *Corresponding Author
}

\begin{abstract}
The title of this paper is " The Forms and Meanings of American Slang Use in "TED 2" Movie Script. The aims of this study are to know and describe the forms and types of slang words and phrases used by the characters in TED 2 movie script, and to analyze the meanings of slangs found in TED 2 movie script. The data were collected from the TED 2 movie scripts. The data were collected through internet source. The data was analyzed by descriptive method. The theory used to analyze the problem was proposed by chapman (1998) about the types and forms of slang, while for the meaning of slang the theory used was proposed by Lyons (1981). The result of data analysis were presented with descriptive method. The findings of the research found that, there are two kind of slangs in the data, there are primary slang and secondary slang. The total number of data of primary slangs was found are twenty one, while for the secondary slangs they are found nineteen. As to the meaning of slang, there are two kind of meaning found in the data, they are literal meaning and figurative meaning.
\end{abstract}

Keywords: Slang, Types, Meaning

\begin{abstract}
Abstrak
Judul dari artikel ini adalah " Bentuk dan Arti Slang America yang digunakan di Film Script “ TED 2". Tujuan dari peneletian ini adalah untuk mengidentifikasikan dan menjelaskan tipe dari kata dan kalimat slang yang digunakan di script film TED 2, dan untuk menganalisis arti dari slang yang ditemukan di film script TED 2. Data dari penelitian ini didapatkan dari script movie TED 2. Data didapatkan dari sumber internet. Data dianalisis dengan menggunakan method descriptive kualitatif. Teori untuk menganalisis masalah pada artikel ini adalah teori dari Chapman (1998) tentang tipe bentuk slang,sedangkan untuk arti dari slang menggunakan teori dari Lyons (1981). Analisis data disajikan dengan method informal. Hasil dari penelitian ini menemukan ada dua tipe slang ditemukan di data,itu adalah slang utama dan slang sampingan. Total dari slang utama yang ditemukan di data adalah 21,sedangkan untuk slang kedua (sampingan) menemukan ada 19 pada data. Dengan tambahan, arti dari slang, menemukan ada dua tipe yang ditemukan di data, itu adalah makna literal dan makna figurative.
\end{abstract}

Katakunci: Slang, Tipe, Arti.

\section{INTRODUCTION}

Language is important for human to communicate and understand each other. However, it is very complex to be easily defined. Many experts have proposed many definitions about language from their own perspective. The study about language itself is called linguistics. given 
the complexity of language, other subdisciplines of linguistics emerges. One of these is sociolinguistics.

Sociolinguistic investigate relationship between language and society with the goal of gaining a better understanding of the language structure and how language function are applied in communication (Wardhaugh 1986:12). The purpose of this paper is to know the reason people speak differently in different social contexts. Sociolinguistics concerns with identifying the social function of the language and conveying the social meaning.

One of the most common phenomena in sociolinguistics that has been studied is the use of special expression in certain social community. For example, special expression used by doctor will be different with expression used by lawyers. This difference of expression use is called slang. Slang is informal language or specific words used by particular group of people (Chapman 1998).

Although slang is not considered a formal speech, but it is used in everyday conversation. Many Americans use slang in their conversation with different purposes. This phenomenon can be found almost in all over of American life. It can be found also in American literary works. One of the intrinsic elements in literary works is the language style. The use of slang supports the existence of language style which is intended to enliven the conversation in the communication.

One of the literary works that uses slang in the conversation is movie. In movie, we can see directly the use of slang words and expressions by actors or actress especially the main characters. The use of slang can give a deep impression to audience.

In this paper, the slang expression used in a movie script is analyzed. Movie script is a list of conversation that should be spoken by the actors or actress. The movie TED 2 was analyzed because it is an adult comedy film, which contained many slang expressions.

Some journal about slang also taken as reference, as follows: first, Appropriation of American Slang by Asian American Youth by Reyes Angela (2005). Second by Zhou \& Fan (2013) entitled A Sociolinguistic Study of American Slang published in Theory and Practice in Language Studie. Third by Wahyu Trimastuti entitled ananalysis of slang word used insocial media (2017). Fourth, Gender analysis on slang language in student daily conversation by Kasmawati Amir,St.azizah (2017). Fifth, An Analysis of American slang in movie"Laugh of loud" by Tiarma Ika Yuliana (2015). Sixth, The use of English in Indonesian Adolescent's slang by I Dewa Putu Wijana ( 2014). Seventh, the use of English slang words in informal communication among $8^{\text {th }}$ semester students of English department in binus university by Muhartoyo; baby Samantha wijaya(2014). Eighth, an analysis of slang words in the lyric fareast movement song as the form of language development and its used in the daily life by Vonny Elisa Oktavia (2017). Ninth, Tropes of slang by Asif Agha(2015). Tenth, analysis on the use of slang on Eminems Lyrics by Hastuti Retno Kuspiyah( 2016).

Based on background, there are some interesting problems: What types of slang are found in TED 2 movie script?, What are the meanings of slang found in TED 2 movie script according to context of situation?. Based on the problems above, the study aims to: To identify and describe the types of slang words and phrases found in TED 2 movie script, To analyze meaning of slang found in TED 2 movie script according to context of situation. 


\section{METHOD}

Research method cover the four aspects as follows:.

\section{Data Source}

The data source in this study was TED 2 movie script. It was downloaded from

https://www.moviequotesandmore.com/t ed-2-quotes/. TED 2 was an American comedy film directed by Seth MacFarlane and was a sequel to the 2012 film TED. This film was produced in 2015 by Scott Stuber, Seth MacFarlane, Jason Clark, and John Jacobs. The production was done under licensed of Media Rights Capital, Fuzzy Door Productions, and Bluegrass Films.TED 2movie told us story about how Ted's fight for his civil rights when authorities ruled that he was a stuffed toy rather than a person. TED 2 movie script was used as data source because it had a genre adult comedy film, which meant slang expression

\section{Method and Technique of Collecting Data}

Documentation method is used as in this study. According to Sugiyono (2013:240) documentation method is a record of past event. The data is collected by selecting the sentences containing slang expression in the movie script. After the slang expressions were found, these expressions were collected into one list. Sentences containing slangs found were numbered.

\section{The Method and Technique of Analyzing Data}

The data were analyzed in order to answer the problems. There were two problems studied in this research. First problem about types of slangs found in
TED 2 movie scripts. This aspect was analyzed by selecting the conversation in the movie script which is containing slang expressions and determine their types according to theory about type of slang from Chapman (1998; 263). Meanwhile, second problem about what the meaning of slang are found in TED 2 movie script was analyzed by understanding the literal and figurative meaning of slang expression according to Oxford dictionary and online American slang dictionary. And fin the meaning according to context of situation using theory the meaning of slang proposed by Lyons $(1981 ; 8)$.

\section{Method and Technique of Presenting Data Analysis}

Descriptive method was used. Descriptive was defined as giving details or something that describes (Sugiyono, 2013). The analysis of the first problem was presented in form of a list of slang found in the movie script. This list contained full sentences or phrases containing slang expression. Meanwhile, the analysis of the second problem was presented in from of descriptive analysis. Every slang expression was described individually in order to find its meaning.

\section{RESULTS AND DISCUSSION}

\section{Analysis of the types of slang}

There are two kinds of slang; the primary slang and the secondary slang. The teenage talk, the speech of urban streets gangs would be the example of primary slang (chapman 1998). The secondary slang deals with the stylistic choice rather than true identification

\section{a. Primary slang}

Teenage talk and speech of urban streets gangs are the example of primary slang. This slang is used in everyday conversation to make the conversation 
between friends and gang more stylish and cooler (Chapman 1998). To clarify the primary slang, there are some data to be analyzed as follows:

\section{DATA 1:}

Tami: This is the best day of ever! Ted: yeah! Baby!

This slang word " baby" is a primary slang because it is used as a general expression by English people on their daily communication. It is not related tosomeone's attitude or something in secret. The conversation taken place at Ted's house, in the night. In this conversation, after Ted and Tamy-Lynn got married, Ted used slang "baby" as affection form of address for the loved one (Tamy-Lynn). The meaning of slang ' baby' is figurative meaning.

DATA 2:

Tami: This is the best day of ever!

Ted: yeah! Baby ! I'm gonna get crazy tonight

This slang 'gonna' is a primary slang because it is an alternative pronunciation used by the user. It is used to in order to make it sound more stylish and cool. The conversation takes place at Ted's house, in the night. The meaning of slang 'gonna' is literal meaning.

\section{b. Secondary slang}

Secondary slang is usually used between group of people and gang. This kind of a slang usually work as a secret code between group member. The slang word and phrase is usually more stylish and quite hard to understand. To clarify the secondary slang (Chapman 1998), there are some data to be analyzed as follows :

DATA 1:

Tami-Lynn: Teddy. This time to get shit faced!
Ted: Okay baby!

This slang phrase "shit faced" is secondary slang because it is usually used by a group of drunken people. This conversation taken place at Ted's house, in the night. In this conversation, TamyLynn used this slang when she finally married with her beloved one, Teddy. She was too happy and decided to be completely drunk. The meaning of slang 'shit faced' is figurative meaning.

DATA 2:

Guy: we're actually about to tie the knot.

Tami-Lynn: Oh, you two going to get married?

This slang phrase "tie the knot" is a secondary slang because it is only used by some group of people. It is secretly used as a replacement of terms married by gay people. This conversation taken place at Ted's house, in the night. This slang spoken when Guy ( Rick's boyfriend) come to Ted's weeding party. The meaning of slang 'tie the knot' is figurative meaning.

\section{Analysis the meaning of slang}

According to Lyons $(1981 ; 121)$ the meaning of an expression is what it refers to, or stands for. This is very popular theory, to explain the meaning of word by pointing to the thing it refers to. This section will discuss the meaning of slang found in ' TED 2' movie script.

a. Tami-Lynn: Teddy, this is the best day ever! I just love you so much!

Ted: I love you ,baby

This slang word is s a primary slang because it is used as a general expression by English people on their daily communication. In this conversation after they got married, Ted used slang "baby" 
as affection form of address for the loved one (Tamy-Lynn).

The slang word " $b a b y$ " in the sentence "I love you too, baby I'm gonna go fifty shades of bear on you tonight!" literarily has meaning a very young child or animal (Oxford Dictionary, 2003).Yet, according to context of situation in this movie, the slang word "baby" is used by Ted as affection form of address for the loved one (Tamy-Lynn). Therefore, the figurative meaning of word "baby" in this sentence is an expression for addressing the loved one.

Tami: This is the best day of ever!

Ted: yeah! Baby !i'm gonna get crazy tonight!

This slang word is a primary slang because it is an alternative pronunciation used by the user. It is used to shorten, alter, or change the sound of a word in order to make it sound stylish and cooler. The slang word "gonna" as shown in the sentence "I'm gonna go fifty shades of bear on you tonight!" comes from word going and to blend become gonna. According to NTC's Thematic dictionary of American Slang (1997), the slang word "gonna" is the construction of "going to". It is typically informal spoken

\section{b. Tami: Teddy! Let's go get shit faced! Ted: Okay!}

This slang phrase "shit faced" is a secondary slang because it is usually used by a group of drunken people.

The slang phrase "shit faced" as shown in the sentence "Let's go get shit faced!"comes from two words "shit" + "faced". The literal meaning word "shit" is feces(Oxford Dictionary, 2003). The word "faced" is the front part of a person's head from the forehead to the chin and be positioned with the face or front toward (someone or
something)(Oxford Dictionary, 2003). In this sentence, the figurative meaning of the slang phrase "shit faced" means to be completely drunk. According to context of situation, in this conversation, TamyLynn used this slang when she finally married with her beloved one, Teddy. She was too happy and decided to be completely drunk.

\section{CONCLUSION}

After analyzing words and phrases of American slang found in the script of the movie TED 2 which consists of the analysis of types and meaning of slang, conclusion can be made.

The types of the slangs expressions used by the characters in TED 2 movies are divided in two types namely primary and secondary slang. From the data there are twenty-one primary slang used by the main and secondary characters in this movie, and there are nineteen secondary slang used by the characters in this movie. The primary slang used by the characters were identified as feeling expression which are used and understood mostly by American. The expressions of the primary slangs used by the characters are baby, gonna, fuck you, bud, asshole, wanna, Goddamn, chick, bastard, son-of-a-bitch, piece of shit, bullshit, hell, bitch, sucks, mother fucker!, dicks, bucks, jackass, scumbag, and honey. Meanwhile, the secondary slangs used by the characters are not commonly used by all American. These expressions are shit faced, tie the knot, Jesus, black cocks, white niggers, wakeup call, fella, jizz, jerking off, pot, butthole, Poindexter, fags, bumsies, classy, spas, Déjà vu, rock on, and bang.

The meaning of the slang used by the characters in the mvie were analyzed in form of its literal and figurative meaning. the literal meaning was traced by using Oxford Dictionary (2003) and the figurative meaning was traced by using 
New Dictionary of American Slang (1987) and NTC's Thematic dictionary of American Slang (1997). Based on the analysis, it was found that all of the slang expressions had two meaning, both literal and figurative meaning unless the expressions of gonna and wanna. These two expressions were only the reconstruction of going to and want to. The primary slangs expressions were used to express the characters' feeling while the secondary slangs were used to express specific information which can only be understood by the speakers.

\section{REFERENCES}

Agha,Asif. 2015.Tropes of Slang.vol 3. November 2015;306-330.

Amir,Kasmawati. 2017. Gender analysis on slang language in student daily conversation. Vol 3, no 2(2017).

Angela, Reyes. 2005. Journal of Sociolinguistic. Appriation of African American slang by Asian American youth. Volume 9 /4, November 2005, ppl 509-532.

Baby Samantha Wijaya,Muhartoyo. 2014. the use of English slang words in informal communication among $8^{\text {th }}$ semester students of English department in binus university. Humanora vol 5 no. 1 april 2014;197-209.

Chapman, Robert L. 1987. A New Dictionary of American Slang. London: Harper \& Row Publisher Inc.

Halliday, M.A.K. (1999). The notion of Context in Language education. In Text and Context in Functional
Linguistics. Philadelphia: John Benjamins Publishing Company.

Holmes, Janet. 1992. An Introduction to Sociolinguistics. New York: Longman group.

Lyons, John. 1981. Language, Meaning and Context. London: Cambridge University press.

Mesly, O. 2015. Creating Models in Psychological Research. EtatsUnis: Springer Press.

Oktavia, Vonny Elisa.2017. an analysis of slang words in the lyric fareast movement song as the form of language development and its used in the daily life. Vol 1,nol (2017)

Retno Kuspiyah,Hastuti. 2016. Analysis on the use of slang on Eminems Lyrics. Vol 1 no 1(2016).

Partridge, Eric. 2004. Slang: Today and Yesterday. London: Routledge and Kegan Paul Ltd.

Spears, Richard A. 1997. NTC's Thematic Dictionary of American Slang. London: McGraw-Hill Education

Sampson, J.A.2003.Oxford Dictionary of English $\quad\left(2^{\text {nd }}\right.$ edition $)$. Oxford: Oxford University Press.

Sugiyono. 2013. Metode Penelitian Kuantitatif, Kualitatif, dan $R \& D$. Bandung: Alfabeta.

Trimukti,Wahyu.2015. An analysis of slang words used in social media. Vol

5 , No 
2(2017):Juli.DOI10.2426/dpp.v5i2 . 497.

Wardhaugh, Ronald. 1986. An Introduction to Sociolinguistics. New York: Basil Blackwell.

Wijana, I Dewa Putu.2014. The use of English in Indonesian Adolescent's slang. Vol. 14 No. 1 - April 2014.

Yuliana, Tiarma Ika.2015. An analysis of American slang in movie "Laugh of loud”. Vol 7 no 1 (2015).

Zhou, Yanchun., and Fan, Yanhong. 2013. A Sociolinguistic Study of American Slang. Theory and Practice in Language Studies, Vol.3, No. 12, pp. 2209-2213, December 2013. doi:10.4304/tpls.3.12.2209-2213 